\begin{tabular}{|c|c|}
\hline & $\begin{array}{l}\text { International Journal of Trend in Scientific } \\
\text { Research and Development (IJTSRD) }\end{array}$ \\
\hline 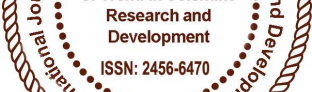 & International Open Access Journal \\
\hline 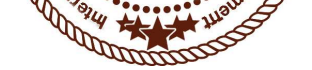 & ISSN No: 2456 - 6470 | www.ijtsrd.com | Volume - 2 | Issue - 1 \\
\hline
\end{tabular}

\title{
Invitro Regeneration of Arabidopsis Thaliana from Suspension and Invitro Cultures and Analysis of Regeneration and Antioxidant Enzyme Levels
}

\author{
Amrina Shafi \\ Research Associate \\ Division of Biotechnology, \\ CSIR-Institute of Himalayan, \\ Bioresource Technology, \\ Palampur, HP, India
}

\author{
Insha Zahoor \\ Assistant Professor, \\ Department of Biotechnology, \\ University of Kashmir, School of \\ Biological Sciences, Srinagar, \\ J\&K, India
}

\author{
Mudasir A Mir \\ Research Associate \\ Centre for Plant Biotechnology, \\ Sher-e-Kashmir University of \\ Agricultural Sciences and \\ Technology of Kashmir, Shalimar, \\ J\&K, India
}

\section{ABSTRACT}

Arabidopsis tissue culture is valuable for any laboratory working on this model plant. Tissue culture methodology facilitates the production of a large number of plants that are genetically identical over a relatively short growth period. Currently this in vitro regeneration system is a good system to study the mechanism by which plants show regenerative plasticity. Plant regeneration is a key technology for successful stable plant transformation, while cell suspension cultures can be exploited for metabolite profiling, kinetic study and mining. In this paper we report methods for the successful and highly efficient in vitro regeneration of plants and production of stable cell suspension lines from cotyledons of Arabidopsis thaliana. It is an easy and reproducible method of regenerating Arabidopsis plants from callus culture. A combination of 6-benzylaminopurine (BAP) and $\alpha$ naphthalene acetic acid (NAA) in a Murashige and Skoog's (MS) based medium gives a high percentage of shoot formation. Further cell suspension culture were used to study the growth kinetics and also for checking level of antioxidant enzymes at different stages of culture. An expression analysis of antioxidant genes such as superoxide dismutase (SOD) and ascorbate peroxidase (APX) was also done at callus, shoot and root regeneration stage. It was found that levels and activity of these antioxidant enzymes were higher at regeneration stage, indicating antioxidant enzyme role in plant morphogenesis. Here we describe a standard protocol for regenerating Arabidopsis plants in tissue culture, and for preparing and observing samples using steriosome and bright field microscopy to study different stages of regeneration.

Keywords: Arabidopsis thaliana, Suspension Culture, Callus Culture, Shoot Induction, Root Induction

\section{INTRODUCTION}

Plants possess a high capacity to regenerate, which has long been utilized for clonal propagation in the form of cutting and grafting (Hartmann et al., 2010; Melnyk and Meyerowitz, 2015). The attempts to regenerate whole individual plants from small tissues or single cells in vitro started in the early 20th century when Haberlandt (1902) proposed the concept of tissue culture. A landmark breakthrough in the history of tissue culture was the discovery that the balance of two exogenously applied plant hormones, namely auxin and cytokinin, could determine the fate of regenerating tissue: high ratios of auxin to cytokinin generally led to root regeneration and high ratios of cytokinin to auxin tended to promote shoot regeneration (Skoog and Miller, 1957). Steward et al. 
(1958) further demonstrated that even single cells from carrot vascular phloem retain totipotency - the capacity to regenerate whole plants - thus highlighting the astonishing regenerative potential of plant somatic cells.

A common mode of plant regeneration both in nature and in vitro is de novo organogenesis, in which plant cuttings or explants first form ectopic apical meristems and subsequently develop shoots and roots. Meristems are specialized plant tissues where new cells, tissues and organs are generated through cell division and differentiation. Plants can also regenerate through somatic embryogenesis in vitro, whereby isolated protoplasts or cells first develop cellular structures similar to zygotic embryos and subsequently generate whole plant bodies. Both of these regeneration processes occur either directly from parental tissues or indirectly via the formation of a callus. Over recent decades, various culture conditions have been established for plant regeneration and utilized for clonal propagation and genetic transformation in diverse plant species. The regenerative capacity of plant cells can be enhanced in vitro when explants are cultured on nutrient media supplemented with plant hormones (Skoog and Miller, 1957; Murashige, 1974; George et al., 2008)root regeneration can also be induced de novo from various mature somatic tissues, and whole plants can be regenerated even from single protoplasts through de novo organogenesis or somatic embryogenesis (Takebe et al., 1971; Zhu et al., 1997; Chupeau et al., 2013).

Regeneration process is controlled by various genes whose expression is governed by certain physical and chemical conditions (Imani et al. 2001; Papadakis et al. 2001). So far, in vitro regeneration has been achieved by a variety of means including treatment with plant growth regulators (PGR), temperature shocks, osmotic stress, and through application of various chemical substances (Szechynska-Hebda et al. 2007; Touraev et al. 1997; Zavattieri et al. 2010). The consequence of these processes has been generally considered as ROS overproduction, which is detrimental for plant as such (Scandalios 1997). However, recent pieces of evidence suggest that ROS participate in signal transduction cascade (Prasad et al. 1994) and have a positive role in plant growth and development (Tian et al. 2003).

A change in the activity of antioxidant enzymes has also been detected during in vitro shoot initiation and development (Batkova et al. 2008; Gupta
2010).Furthermore, it has been reported that the cytosolic $\mathrm{Cu} / \mathrm{Zn}$ - SOD was induced in regenerating tobacco protoplasts (Papadakis et al. 2001), which supports the hypothesis that SOD is involved in plant morphogenesis. The present study was aimed to study callus growth and in vitro regenerative capacity of the different tissues of Arabidopsis. We also showed expression and activity of antioxidant genes has a role to play in plant morphogenesis. Our results suggest that proper maintenance of redox homeostasis is crucial for successful regeneration at the early stages of shoot organogenesis.

\section{MATERIALS AND METHODS}

\section{Plant growth, callus induction, and regeneration}

Arabidopsis seeds were surface sterilized, sown in petri dishes containing Murashige and Skoog (MS)medium. The plates were kept at $4{ }^{\circ} \mathrm{C}$ for 2 days and then shifted to $21 \pm 1{ }^{\circ} \mathrm{C}$. After 10 days of germination, cotyledons were excised from seedlings and cut into two pieces and placed on MS callus induction medium containing $30 \mathrm{~g} \mathrm{1-1}$ sucrose and 8.0 g 1-1 agar (Sigma-Aldrich, St. Louis, MO, USA), supplemented with 1 mg 1-1 2,4dichlorophenoxyacetic acid (2,4-D) (Sigma-Aldrich, St. Louis, MO, USA). The explants were cultured in the dark at $25 \pm 2{ }^{\circ} \mathrm{C}$. Callus formation started after 1 week of inoculation on callus induction medium. After 1 month, compact proliferating callus was selected and transferred to fresh MS medium with 1.0 mg 1-1 2,4-D, $30 \mathrm{~g} \mathrm{1-1}$ sucrose, and $8.0 \mathrm{~g} \mathrm{1-1}$ agar. After 1-month subculture, proliferating callus was transferred to regeneration medium (half strength MS medium with $30 \mathrm{~g} \mathrm{1-1}$ sucrose, $8.0 \mathrm{~g} 1-1$ agar, supplemented with $0.5-1.0 \mathrm{mg} \mathrm{1-1} 2,4-\mathrm{D}$, and $0.5-1.0$ mg 1-1 benzylaminopurine (BAP) (Sigma-Aldrich, St. Louis, MO, USA) for regeneration in a culture room with a 16-h photoperiod (60-70 $\mu \mathrm{mol} \mathrm{m}-2 \mathrm{~s}-1$ cool white fluorescent irradiance) for 4 weeks at $25 \pm 2{ }^{\circ} \mathrm{C}$. Callus with clearly differentiated shoots were counted as regenerated, with each piece of callus counted as one unit. After 4 weeks, the regenerated plantlets were transferred to $100-\mathrm{ml}$ flasks containing the same medium for further growth. SOD activity and $\mathrm{H} 2 \mathrm{O} 2$ content were determined at different stages of culture. Regeneration frequency was calculated as the number of regenerated explants per total number of cultured explants. Three replications were used in each experiment. 


\section{Measurement of callus growth}

Following callus induction after 3 weeks of culture, callus was aseptically transferred onto liquid medium in culture flasks. The flasks were incubated in the dark at $27 \pm 1{ }^{\circ} \mathrm{C}$ for 4 weeks. Growth kinetics was studied by determination of fresh and dry weights of fresh callus of $5,10,15,20,25$, and 30 days old. Dry weight of fresh callus was determined after drying in a vacuum oven at $65{ }^{\circ} \mathrm{C}$ until constant weight. The cultures were incubated for $16-\mathrm{h}$ photoperiods at 25 ${ }^{\circ} \mathrm{C}$.

\section{Microscopy}

Explants were collected at 0, 1, 2, 3, and 4 weeks from initiation and evaluated using scanning electron microscopy (SEM) and light microscopy (LM). Samples were fixed informalin, glacial acetic acid, and $50 \%$ ethyl alcohol (FAA)(1:1:18) at room temperature. Samples were subsequently dehydrated in a tertiary butyl alcohol series, embedded in paraffin (melting point $58-60{ }^{\circ} \mathrm{C}$ ), and $8-10-\mathrm{mm}$ thick sections were cut using a Finesee microtome. Sections were stained with $1 \%$ safranin in water and with $4 \%$ fast green in clove oil for $4 \mathrm{~h}$ and for $30 \mathrm{~s}$, respectively. These were mounted in Canada balsam and examined using bright fieldmicroscope (Zeiss LSM510 meta GmbH, Germany) equipped with a Zeiss Axiovert $100 \mathrm{M}$ inverted microscope.

\section{SOD and APX enzyme activity assay}

Leaf samples $(100 \mathrm{mg})$ were homogenized in a pre cooledmortar in homogenizing buffer containing 2 mM EDTA, $1 \mathrm{mM}$ DTT, $1 \mathrm{mM}$ PMSF, $0.5 \%$ (v/v) Triton-X100 and10 \% (w/v) PVPP in $50 \mathrm{mM}$ phosphate buffer $\mathrm{pH}$ 7.8.For APX activity, homogenizing buffer contained ascorbatein addition and the buffer $\mathrm{pH}$ was set to 7.0. Thehomogenate was transferred to $1.5 \mathrm{ml}$ tubes and centrifugedat 13,000 rpm for $20 \mathrm{~min}$ at $4{ }^{\circ} \mathrm{C}$. The supernatant was collected and total SOD and APX activities were estimated. The total SOD activity was measured by adding5 $\mu 1$ enzyme extract to reaction mixture $(200 \mu \mathrm{l})$ containing $1.5 \mu \mathrm{m}$ riboflavin, $50 \mu \mathrm{m}$ NBT, $10 \mathrm{mM}$ Dlmethionine and $0.025 \%(\mathrm{v} / \mathrm{v})$ triton-X100 in $50 \mathrm{mM}$ phosphate buffer. One unit of enzyme activity was defined as the amount of enzyme required for $50 \%$ inhibition of NBT reduction per min at $25{ }^{\circ} \mathrm{C}$. Specific activity of SOD was calculated accordingly. APX activity was determined by following the oxidation rate of ascorbate at $290 \mathrm{~nm}$ as described by Nakano and Asada (1981). Protein content was estimated according to the dye binding method of Bradford using BSA as standard (Bradford 1976).

\section{RT-PCR Analysis}

Total RNAwas isolated from transgenic and the wildtype Arabidopsis plants using Total RNA Extraction Kit (RealGenomics). One microgram of total RNA was used for oligo (dT) primed first-strand cDNA synthesis in $20-\mu 1$ reactionusing Superscript III reverse transcriptase (Invitrogen). This cDNA was used in 27-cycle PCR using gene specific primers for PaSOD gene. Constitutively expressed 26S rRNA gene was amplified simultaneously in 27 cycles to ensure equal amounts of template cDNA used.

\section{Statistical analysis}

All experiments were conducted with at least threeindependent repetitions in triplicate. All values areshown as the mean \pm standard deviation. The statisticalanalysis was performed using Statistica software (v.7). The statistical significance between the mean values was assessed by Analysis of Variance (ANOVA) applying Duncan' $s$ multiple range test (DMRT). A probability level of $\mathrm{P} \leq 0.05$ was considered significant.

\section{RESULTS AND DISCUSSION}

\section{Callus Induction, Initiation of Suspension culture and Growth Kinetic Study}

In the present study, cotyledons of Arabidopsis plants were used as explants due to their high regeneration potential as suggested by various previous studies (Ozcan et al. 1992; Patton and Meinke 1988; Mante et al. 1989). In addition to this root and stem section of Arabidopsis was also used to induce callus. After 1 week of inoculation on $1 \mathrm{mg} 1^{-1} 2,4 \mathrm{D}$, callus formation has initiated. Callus Induction was faster in cotyledons (CT) followed by root (RT) and stem sections (IF). Callus initiation is the primary stage in many tissue culture processes for the establishment of cell suspension cultures(Kumar and Kanwar 2007; Ngara et al. 2008). Once callus was initiated under invitro conditions, inoculum was used for suspension culture (Liquid MS, supplemented with $1 \mathrm{mg} \mathrm{l}^{-1} 2,4$ D). The growth of callus was determined based on the fresh and dry weights after 10, 20 and 20 days of suspension culture.Growth kinetics showed a typical curve with lag phase, exponentialphase followed by stationary phase after incubation. The pattern of the growth curve obtained in CT, RT and IF was different (Fig.1). Upon transferring the calli ofCT and (RT and 
IF) to the suspension medium, verylittle increase in biomass was observed during the first 4 daysof culture (the lag phase). After 6 days of culture, the calliwere found in their exponential phase as the cells rapidlydivided and proliferated. After 14 days, culture reached thestationary phase. While in WT, exponential phase began after 14 days of incubation and stationary phase was reached after22 days. Growth rates during the exponential phase in IF,

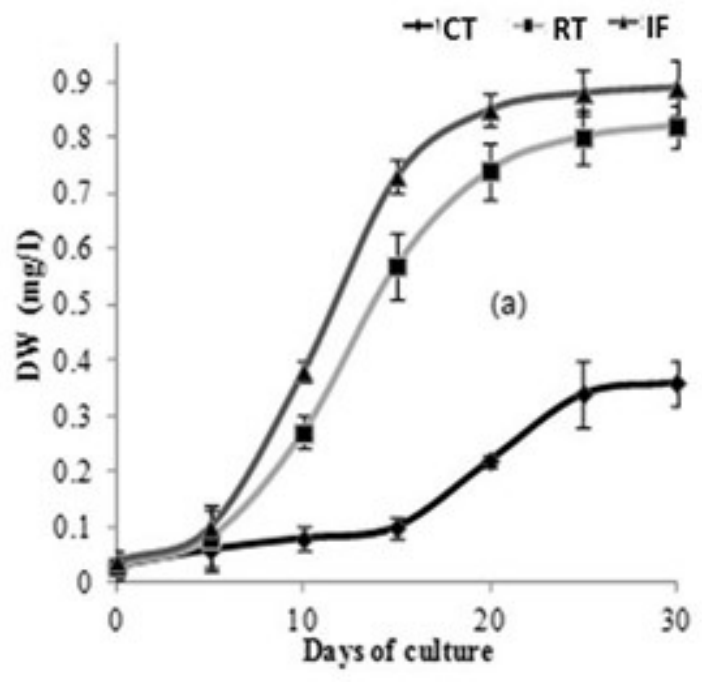

RTand CTwere 0.22, 0.57, and 0.73 g (dry weight)/day, respectively, (Fig.1 ) while on the basis of fresh weight,growth rates during the exponential phase in IF, RT and CTwere 0.38, 0.98, and $1.22 \mathrm{~g}$ (fresh weight)/day, respectively(Fig. 1). These results clearly demonstrate that growthrate of CT calli was significantly higher than that of RT and IFcalli.

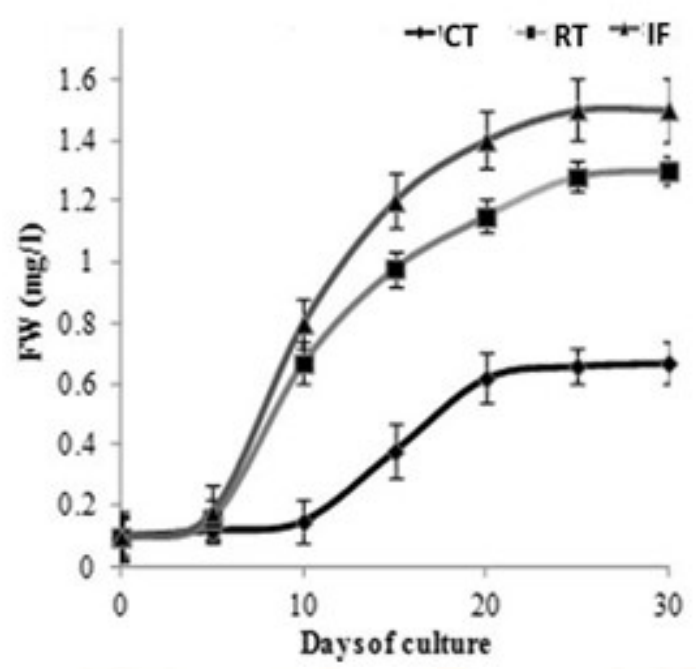

Fig.1 Growth curve analysis of callus from different tissues cotyledons (CT), root (RT) and Inflorescence (IF) based on d dry weight (DW mg/l) and e fresh weight (FW mg/l), which were determined every 2 days after inoculation. Bar indicates the standard deviation $(\mathrm{n}=3)$.

\section{Invitro Regeneration Frequency on different concentration of BAP and NAA}

Calli from IF, RT and CT regenerated shoots when cultured on the regeneration media with different concentrations of BAP and NAA (Table 1). Transfer of callus to regeneration media led to the formation of meristemoids. The meristemoids (nodules or growth centers) are localized clusters of cambium-like cells which may become vascularized due to the appearance of tracheid cells in the center. Formation of meristemoids in callus cultures may represent their association with an early stage development of shoot bud (Kulchetscki et al. 1995). However, an early shoot initiation response was observed from the $\mathrm{CT}$ as compared to IF and RT calli on the regeneration medium containing $0.5 \mathrm{mg} 1-1 \mathrm{NAA}$ and $1.0 \mathrm{mg} \mathrm{l}-1$ BAP. After 2 weeks on the regeneration medium, shoot meristem appeared in approximately $70 \%$ CTcalli (Table 1).

Table 1: Callus induction and shoot regeneration from Arabidopsis Cotyledons (CS), Roots (RT) and Inflorescence (IF) tissues

\begin{tabular}{|l|l|l|l|l|l|l|l|l|}
\hline $\begin{array}{l}\text { Tissue } \\
\text { s }\end{array}$ & \multicolumn{2}{|l}{ Average diameter $(\mathrm{mm})$ of calli in MS media } & \multicolumn{3}{l|}{ Percent shoot regeneration in primary calli } \\
\hline & MS1 & MS2 & MS3 & MS4 & MS1 & MS2 & MS3 & MS4 \\
\hline RT & $\begin{array}{l}5.36 \pm 0.06 \\
\mathrm{~h}\end{array}$ & $7.1 \pm 0.11 \mathrm{~d}$ & $4.36 \pm 0.09 \mathrm{i}$ & $4.06 \pm 0.06 \mathrm{i}$ & $25.1 \pm 0.48 \mathrm{~h}$ & $30.92 \pm 0.48 \mathrm{f}$ & $19.92 \pm 0.48 \mathrm{i}$ & $15.18 \pm 0.48 \mathrm{j}$ \\
\hline CS & $7.92 \pm 0.09 \mathrm{c}$ & $13.8 \pm 0.13 \mathrm{a}$ & $\begin{array}{l}5.94 \pm 0.06 \\
\mathrm{e}\end{array}$ & $\begin{array}{l}7.08 \pm 0.13 \\
\mathrm{~d}\end{array}$ & $\begin{array}{l}60.16 \pm 0.65 \\
\mathrm{c}\end{array}$ & $80.08 \pm 0.85 \mathrm{a}$ & $\begin{array}{l}35.08 \pm 0.48 \\
\mathrm{e}\end{array}$ & $\begin{array}{l}36.92 \pm 0.48 \\
\mathrm{~d}\end{array}$ \\
\hline IF & $5.94 \pm 0.06 \mathrm{f}$ & $\begin{array}{l}11.1 \pm 0.13 \\
\mathrm{~b}\end{array}$ & $5.4 \pm 0.06 \mathrm{~g}$ & $5.82 \pm 0.08 \mathrm{f}$ & $34.9 \pm 0.70 \mathrm{e}$ & $\begin{array}{l}62.87 \pm 1.22 \\
\mathrm{~b}\end{array}$ & $29.6 \pm 0.31 \mathrm{f}$ & $\begin{array}{l}28.16 \pm 0.32 \\
\mathrm{~g}\end{array}$ \\
\hline
\end{tabular}


Each value represents mean $\pm \mathrm{SE}$ of five replicates for each parameter. The induction media contained $1 \mathrm{mg} \mathrm{1-1}$ 2, 4-D and regeneration media supplemented with BAP and NAA in different concentrations, MS1 (0.5 mg 1-1 NAA/0.5 mg 1-1 BAP), MS2 (0.5 mg 1-1 NAA/1 mg 1-1 BAP), MS3 (1 mg 1-1 NAA/0.5 mg 1-1 BAP) and MS4 (1 mg 1-1 NAA/1 mg 1-1 BAP). In each section of the table, means were compared with ANOVA and data followed by the same letters within the columns are not significantly different at the level of $\mathrm{P} \leq 0.05$, as determined by a least-significant difference (LSD)

\section{Expression analysis of antioxidant genes during different Stages of Culture}

RT-PCR expression analysis of SOD and APX enzymes at callus stage (CS), shooting stage (SS) and rooting Stage (RS) was done (Table 2). It was observed that expression of these gene were induced at SS and RS stages, indicating role of SOD and APX genes in shoot and root regeneration (Fig. 2).Numerous studies have been reported relating to the variation in the patterns of the antioxidant enzyme activity during different stages of organogenesis(Franck et al. 1998; Chen and Ziv 2001; Racchi et al. 2001; Meratan et al. 2009; Vatankhah et al. 2010).

Table 2: Primer sequence, PCR conditions, and amplicon size for the PaSOD and 26S rRNA (reference gene) used for semi quantitative PCR

\begin{tabular}{|c|c|c|c|}
\hline Genes & Sequence 5 ' to $3{ }^{\prime}$ & PCR Conditions & $\begin{array}{l}\text { Amplicon } \\
\text { Size (bp) }\end{array}$ \\
\hline AtSOD & $\begin{array}{l}\text { F: TGCCATGGCGAAAGGAGTTGCAG } \\
\text { R:ATAGATCTGCGCCCTGGAGACCAATGATG }\end{array}$ & $\begin{array}{l}94{ }^{\circ} \mathrm{C}, 4 \min ; 94{ }^{\circ} \mathrm{C}, 1 \\
\min , 56{ }^{\circ} \mathrm{C}, 30 \mathrm{~s}, 72{ }^{\circ} \mathrm{C}, 1 \\
\min , 27 \text { cycles; } 72{ }^{\circ} \mathrm{C}, 7 \\
\min \end{array}$ & 456 \\
\hline AtAPX & $\begin{array}{l}\text { F: ATAGATCTGATGGCTGCACCGATTGTT } \\
\text { R: TAAGTAGTCTTCATCCTCTTCCGGATCTC }\end{array}$ & $\begin{array}{l}94{ }^{\circ} \mathrm{C}, 4 \min ; 94{ }^{\circ} \mathrm{C}, 1 \\
\min , 57{ }^{\circ} \mathrm{C}, 30 \mathrm{~s}, 72{ }^{\circ} \mathrm{C}, 1 \\
\min , 27 \text { cycles; } 72{ }^{\circ} \mathrm{C}, 7 \\
\min \end{array}$ & 861 \\
\hline 26S rRNA & $\begin{array}{l}\text { F:CACAATGATAGGAAGAGCCGAC } \\
\text { R:CAAGGGAACGGGCTTGGCAGAATC }\end{array}$ & $\begin{array}{l}94{ }^{\circ} \mathrm{C}, 4 \min ; 94{ }^{\circ} \mathrm{C}, 1 \\
\min , 57{ }^{\circ} \mathrm{C}, 30 \mathrm{~s}, 72{ }^{\circ} \mathrm{C}, 1 \\
\min , 27 \text { cycles; } 72{ }^{\circ} \mathrm{C}, 7 \\
\min \end{array}$ & 534 \\
\hline
\end{tabular}

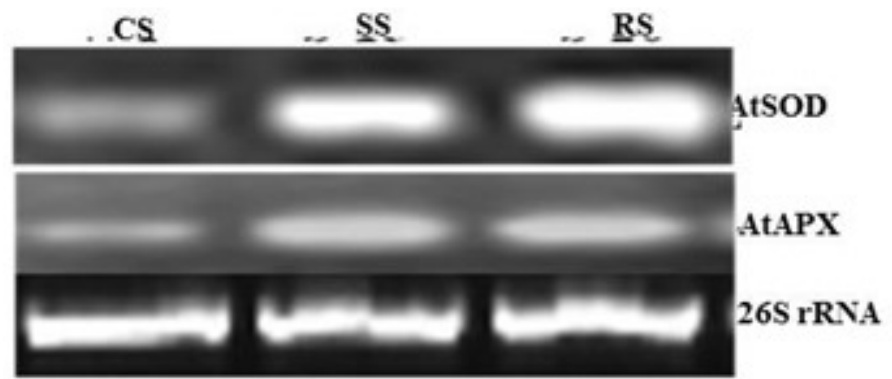

Fig.2 Expression analysis of callus stage (CS), Shooting stage (SS) and Rooting Stage (RS). 26S rRNA was used as the loading control.

Enzyme Activity Assay of SOD and APXduring different Stages of Culture

In the present study, SOD and APX activity was found to vary among SS (shoot stage), RS (root stage) and CS (callus stage) tissues at each stage of culturing. SOD and APX levels were found to be decreased in CS comparing to that of SS and RS stage, then increased in regenerated shoots and roots (Fig. 3). In the case of RS and CS, SOD and APX activity was found to be higher than that of CS at all the stages. However, the increase in the SOD and APX activity of RS and CSlines as compared to WT was more during the regeneration stage. Similar 

observations have also been reported earlier by few groups (Bagnoli et al. 1998; Cui et al. 1999).
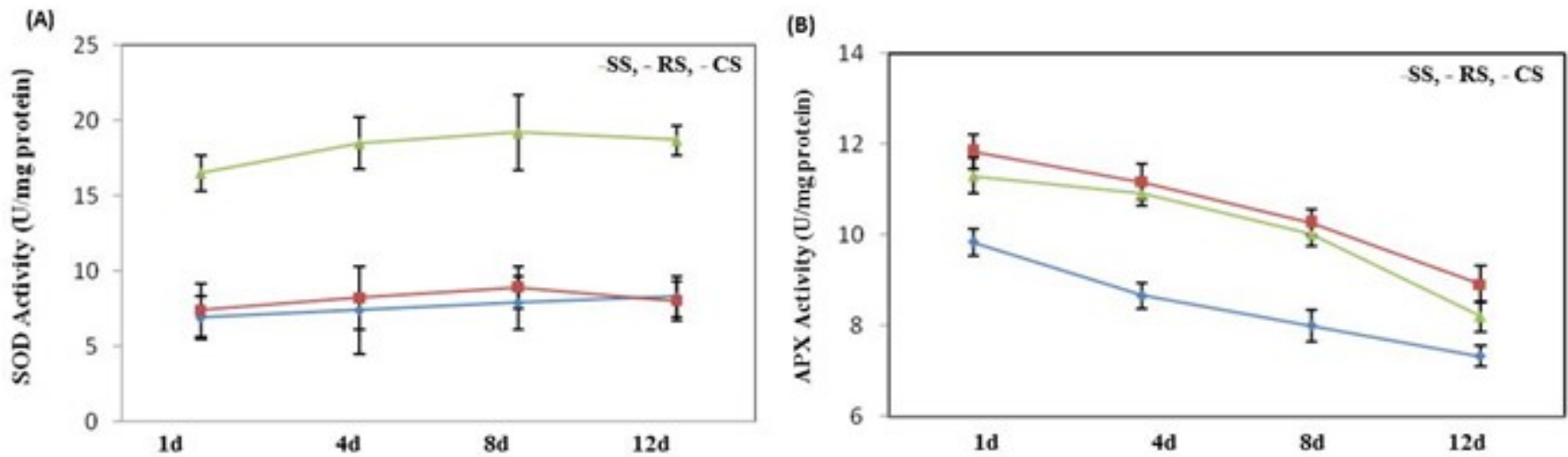

Microscopic Study of different Stages of Invitro regeneration

Under sterosome, different stages of invitro regeneration of Arabidopsis cotyledons were observed. After 1 week of inoculation on $2,4 \mathrm{D}$, callus formation was observed (Fig. 5). Callus turned into green meristemoid like structures after 3 weeks of

inoculation of callus on MS media supplemented with BAP and NAA. Theses meristemoid like structures started regenerating leaf primordia like structures after 4 to 4.5 week period of inoculation. After completion of 5 week shoo regeration were observed from the cotyledonary explants (Fig. 5).

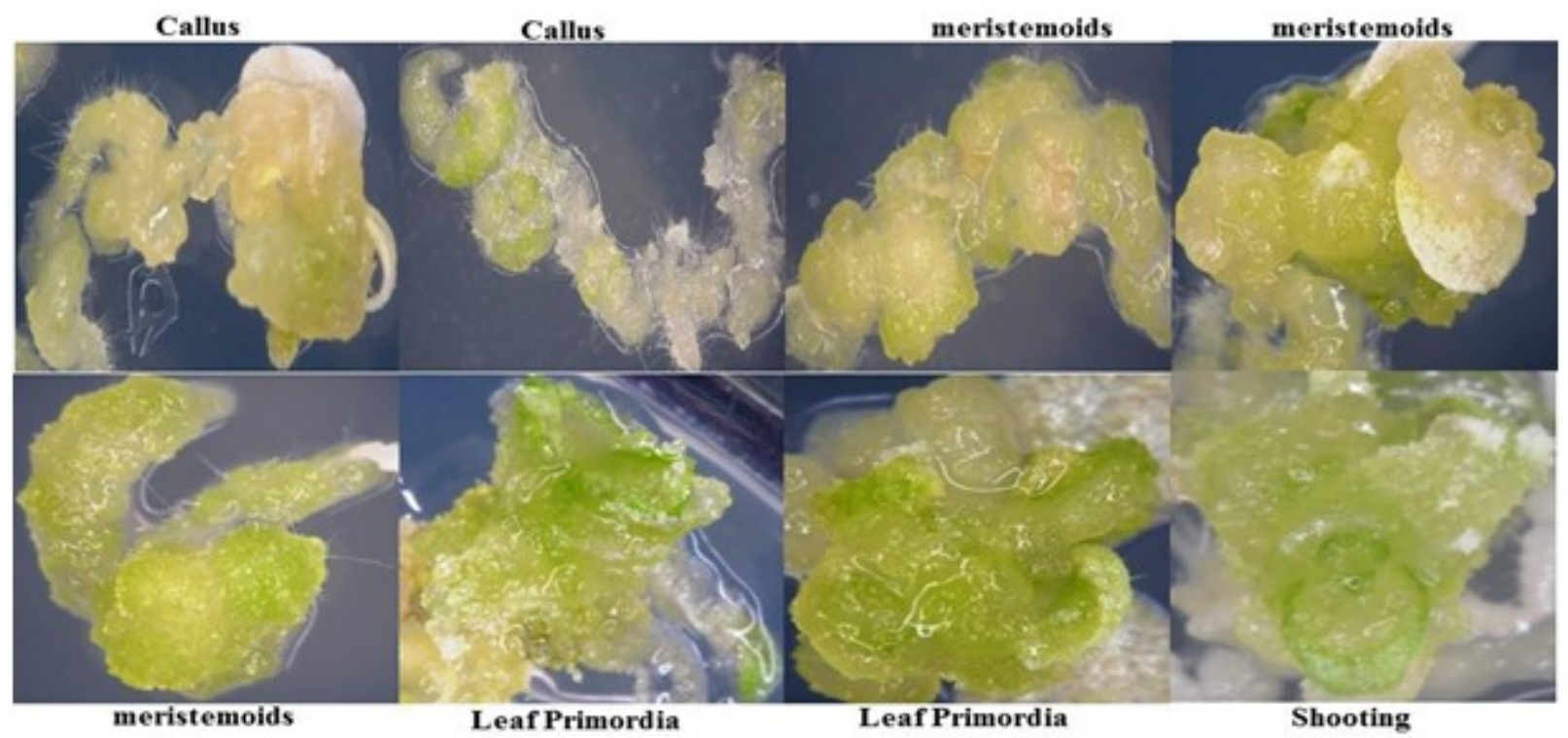

Fig.5 Micrographs observed under sterosome of Callus induction, Shoot meristemoids formation and shoot Induction in media supplemented by 2,4 D followed by BAP and NAA.

\section{Acknowledgments}

This work was supported by grants from the Councilof Scientific and Industrial Research (CSIR), New Delhi, India, in theformof Network Projects PlaGen (BSC0107) and SIMPLE (BSC0109) atthe CSIR-IHBT. As acknowledge fellowships awarded by the CSIR, India.

\section{REFERENCES}

[1] Alscher RG, Erturk N, Heath LS (2002) Role of superoxide dismutases (SODs) in controlling oxidative stress in plants. J Exp Bot 53:13311341

[2] Arnon D (1949) Copper enzymes in isolated chloroplasts. polyphenol oxidase in Beta vulgaris. Plant Physiol 24:1-14 
[3] Asada K (1994) Production and action of active oxygen species in photosynthetic tissues, causes of photooxidative stress and amelioration of defense systems in plants, In: Foyer $\mathrm{CH}$, Mullineaux PM (eds), CRC Press, Boca Raton, FL, pp 77-104

[4] Badawi GH, Yamauchi Y, Shimada E, Sasaki R, Kawano N, Tanaka K, Tanaka K (2004) Enhanced tolerance to salt stress and water deficit by overexpressing superoxide dismutase in tobacco (Nicotiana tabacum) chloroplasts. Plant Sci 166:919-928

[5] Bagnoli F, Capuana M, Racchi ML (1998) Developmental changes of catalase and superoxide dismutase in zygotic and somatic embryos of horse chestnut. Aust J Plant Physiol 25:909-913

[6] Barrs HD, Weatherley PE (1962) A reexamination of the relative turgidity technique for estimating water deficits in leaves. Aust J Biol Sci 15:413-428

[7] Bassuner BM, Lam R, Lukowitz W, Yeung E C (2007) Auxin and root initiation in somatic embryos of Arabidopsis. Plant Cell Rep 26:1-11

[8] Bates L, Waldren R, Teare ID (1973) Rapid determination of free proline for water-stress studies. Plant Soil 39:205-207

[9] Batkova P, Pospisilova J, Synkova H (2008) Production of reactive oxygen species and development of antioxidative systems during in vitro growth and ex vitro transfer. Biol Plant 52:413-422

[10] Bechtold N, Ellis J, Pelletier G (1993) In planta Agrobacterium mediated gene transfer by infiltration of adult Arabidopsis thaliana plants, CR Academy of Sciences Paris, Life Sciences 316:1194-99

[11] Blokhina O, Violainen E, Fagerstedt KV (2003) Antioxidants, oxidative damage and oxygen deprivation stress. a review. Ann Bot 91:179194

[12] Bohnert HJ, Jensen RG (1996) Strategies for engineering water stress tolerance in plants. Trends Biotechnol 14: 89-97.

[13] Chatzidimitriadou K, Nianiou-Obeidat I, Madesis P, Perl-Treves R, Tsaftaris A (2009) Expression of SOD transgene in pepper confer stress tolerance and improve shoot regeneration. Electron J Biotech 12:1 - 8.

[14] Chen J, Ziv M (2001) The effect of an cymidol on hyperhydricity, regeneration, starch and antioxidant enzymatic activities in liquidcultured Narcissus. Plant Cell Rep 20:22-27

[15] Cui K, Xing G, Liu X, Xing G, Wang Y (1999) Effect of hydrogen peroxide on somatic embryogenesis of Lycium barbarum L. Plant Sci 146:9-16

[16] Foyer CH, Descourvierse P, Kunert KJ (1994) Protection against oxygen radicals: an important defense mechanism studied in transgenic plants. Plant Cell Environ 17:507-523

[17] Foyer CH, Lopez-Delgado H, Dat JF, Scott IM (1997) Hydrogen peroxide and glutathioneassociated mechanisms of acclimatory stress tolerance and signaling. Plant Physiol 100:241254

[18] Franck T, Kevers C, Penel C, Greppin H, Housman H, Gaspar T (1998) Reducing properties and markers of lipid peroxidation in normal and hyperhydrating shoots of Prunu savium L. J Plant Physiol 153:339-346

[19] Gill T, Sreenivasulu Y, Kumar S, Ahuja PS (2010) Over-expression of superoxide dismutase exhibits lignification of vascular structures in Arabidopsis thaliana. J Plant Physiol 167:757760

[20] Gupta D (2010) Role of free radicals and antioxidants in in vitro morphogenesis. In: Gupta D (ed) Reactive oxygen species and antioxidants in higher plants. CRC Press, pp 230-247

[21] Halder KP, Burrage SW (2003) Drought stress effects on water relations of rice grown in nutrient film technique. Pakistan J Biol Sci 6: $441-446$

[22] Hasegawa PM, Bressan RA, Zhu JK, Bohnert HJ (2000) Plant cellular and molecular responses to high salinity. Annu Rev Plant Biol 51: 463-499.

[23] Imani J, Tran Thi L, LangenG, Arnholdt-Schmitt B, Roy S, Lein C, Kumar A, Neumann KH (2001) Somatic embryogenesis and DNA organization of genomes from selected Daucus species. Plant Cell Rep 20:537-541 
International Journal of Trend in Scientific Research and Development (IJTSRD) ISSN: 2456-6470

[24] Klaus A, Heribert H (2004) Reactive oxygen species: metabolism, oxidative stress, and signal transduction. Annu Rev Plant Biol 55:373-399

[25] Koster KK, Lynch DV (1992) Solute accumulation and compartmentation during the cold acclimation of puma rye. Plant Physiol 98:108-113

[26] Kulchetscki L, Harry IS, Yeung EC, Thorpe TA (1995) In vitro regeneration of Pacific silver fir (Abies amabilis) plantlets andhistological analysis of shoot formation. Tree Physiol. 15:727-738.

[27] Kumar N, Bhatt RP (2006). Transgenics: An emerging approach for cold tolerance to enhance vegetables production in high altitude areas. Indian J Crop Sci 1: 8-12

[28] Kumar S, Kanwar JK (2007) Plant regeneration from cell suspension in Gerbera gamesonii Bolus. J Fruit Ornam Plant Res 15: 157-166

[29] Kumar S, Sahoo R, Ahuja PS (2002) Isozyme of autoclavable superoxide dismutase (SOD), a process for the identification and extraction of the SOD in cosmetic, food and pharmaceutical compositions. US Patent No. 6,485950 B1.

[30] Kumar V, Shriram V, KaviKishor PB, Jawali N, Shitole MG (2010) Enhanced proline accumulation and salt stress tolerance of transgenic indica rice by over-expressing P5CSF129A gene. Plant Biotechnol Rep 4:3748

[31] Libik M, Konieczny R, Pater B, Slésak I, Miszalski Z (2005) Differences in the activities of some antioxidant enzymes and in $\mathrm{H}_{2} \mathrm{O}_{2}$ content during rhizogenesis and somatic embryogenesis in callus cultures of the ice plant. Plant Cell Rep 23:834-841

[32] Lopez AD, Ahmad OB, Guillot M, Ferguson BD, Salomon JA, Murray CJL, Hill KH (2002) World mortality in 2000: Life tables for 191 countries. Geneva WHO

[33] Luo JP, Jiang ST, Pan LJ (2001) Enhanced somatic embryogenesis by salicylic acid of Astragalus adsurgens Pall: relationship with $\mathrm{H}_{2} \mathrm{O}_{2}$ production and $\mathrm{H}_{2} \mathrm{O}_{2}$-metabolizing enzyme activities. Plant Sci 161:125-132

[34] Lutts S, Kinet JM, Bouharmont J (1996) NaClinduced senescence in leaves of rice (Oryza sativa L.) cultivars differing in salinity resistance. Ann Bot 78:389-398

[35] Madden JI, Jones CS, Auer CA (2005) Modes of regeneration in Pelargonium hortorum (Geraniaceae) and three closely related species. In Vitro Cell Dev Biol Plant 41:37-46

[36] McKown R, Kuroki G, Warren G (1996) Cold responses of Arabidopsis mutants impaired in freezing tolerance. J Exp Bot 47:1919-1925

[37] Munns R, Tester M (2008) Mechanisms of salinity tolerance. Annu Rev Plant Biol 59: 651681

[38] Mante S, Scorza R, Cordts J (1989) A simple, rapid protocol for adventitious shoot development from mature cotyledons of Glycine max cv Bragg. In Vitro Cell Dev Biol 25: 385 388

[39] Matysik J, Bhalu AB, Mohanty P (2002) Molecular mechanisms ofquenching of reactive oxygen species by proline under stress in plant. Curr Sci 82:525-532

[40] Meratan AA, Ghaffari SM, Niknam V (2009) In vitro organogenesis and antioxidative enzymes activity in Acanthophyllum sordidum. Biol Plant $53: 5-10$

[41] Murashige T, Skoog F (1962) A revised medium for rapid growth and bio assays with tobacco tissue cultures. Physiol Plant 15:473-497

[42] Ngara R, Rees J, Ndimba BK (2008) Establishment of sorghum cell suspension culture system for proteomics studies. Afr J Biotechnol 7:744-749

[43] Ozcan S, Barghchi M, Draper J (1992) Highfrequency adventitious shoot regeneration from immature cotyledons of pea (Pisum sativum L). Plant Cell Rep 11:44-47

[44] Papadakis AK, Roubelakis-Angelakis KA (2002) Oxidative stress could be responsible for the recalcitrance of plant protoplasts. Plant Physiol Biochem 40:549-559

[45] Papadakis AK, Siminis CI, RoubelakisAngelakis KA (2001) Reduced activity of antioxidant machinery is correlated with suppression of totipotency in plant protoplasts. Plant Physiol 126:434-444 
International Journal of Trend in Scientific Research and Development (IJTSRD) ISSN: 2456-6470

[46] Patton D, Meinke D (1988) High-frequency plant regeneration from cultured cotyledons of Arabidopsis thaliana. Plant Cell Rep 7:233-237.

[47] Perl-Treves R, Galun E (1991) The tomato $\mathrm{Cu}$, $\mathrm{Zn}$ superoxide-dismutase genes are developmentally regulated and respond to light and stress. Plant Mol Biol 17:745-760

[48] Prasad TK, Anderson MD, Martin BA, Steward CR (1994) Evidence for chilling-induced oxidative stress in maize seedlings and a regulatory role for hydrogen peroxide. Plant Cell 6: $65-74$

[49] Pua EC, Gong HB (2004) Regulation of plant morphogenesisin vitro. Biotechnology in Agriculture and Forestry, vol 54., In: Pua EC, Douglas CJ (eds), Brassica. Berlin: SpringerVerlag, pp 83-102

[50] Racchi ML, Bagnoli F, Balla I, Danti S (2001) Differential activity of catalase and superoxide dismutase in seedlings and in vitro micropropagated oak (Quercus robur L.). Plant Cell Rep 20:169-174

[51] Salaj J, Petrovska B, Obert B, Pret'ova A (2005) Histological study of embryo-like structures initiated from hypocotyls segments of flax (Linum usitatissimum L.). Plant Cell Rep 24:590-595

[52] SamisK, Bowley SR, Mckersie BD (2002) Pyramiding Mn superoxide dismutase transgenes to improve persistence and biomass production in alfalfa. J Exp Bot 53:1343-1350

[53] Santos C, Azevedo H, Caldeira G (2001) In situ and in vitro senescence induced by $\mathrm{KCl}$ stress: nutritional imbalance, lipid peroxidation and antioxidant metabolism. J Exp Bot 52:351-360

[54] Scandalios JG (1997) Molecular genetics of superoxide dismutases. In: J.G. Scandalios. [ed.]. Oxidative Stress and the Molecular Biology of Antioxidant Defenses. Cold Spring Harbor Laboratory Press, Plain view, NY, USA, pp 527-568

[55] Schubert D, Lechtenberg B, Forsbach A, Gils M, Bahadur S, Schmidt R (2004) Silencing in Arabidopsis T-DNA transformants: the predominant role of a gene-specific RNA sensing mechanism versus position effects. Plant Cell 16:2561-72
[56] Shi H, Lee BH, Wu SJ, Zhu JK (2003) Over expression of a plasma memebrane $\mathrm{Na}+/ \mathrm{H}+$ antiporter gene improves salt tolerance in Arabidopsis thaliana. Nat Biotechnol 21: 81-85

[57] Sonja V, Noctor G, Foyer CH (2002) Are leaf hydrogen peroxide concentrations commonly overestimated? The potential influence of artefactual interference by tissue phenolics and ascorbate. Plant Physiol Bioch 40:501-507

[58] Szechynska-Hebda M, Skrzypek E, Dabrowska G, Koscielniak J, Filek M, Wedzony M (2007) The role of oxidative stress induced by growth regulators in the regeneration process of wheat. Acta Phys Plant 29:327-337

[59] Tang G, Reinhart BJ, Bartel DP, Zamore PD (2003) A biochemical framework for RNA silencing in plants. Gene Dev 17:49-63

[60] Tian M, Gu Q, Zhu M (2003) The involvement of hydrogen peroxide and antioxidant enzymes in the process of shoot organogenesis of strawberry callus. Plant Sci 165:701-707.

[61] Touraev A, Vicente O, Heberle-Bors E (1997) Initiation of microspore embryogenesis by stress. Trends Plant Sci 2:297-302

[62] Vatankhah, E, Niknam E, Ebrahimzadeh H (2010) Activity of antioxidant enzyme during in vitro organogenesis in Crocus sativus. Biol Plant 54:509-514

[63] Wise RR, Naylor AW (1987) Chilling-enhanced photooxidation: evidence for the role of singlet oxygen and superoxide in the breakdown of pigments and endogenous antioxidants. Plant Physiol 83:278-282

[64] Zavattieri MA, Frederico AM, Lima M, Sabino R, Arnholdt-Schmitt B (2010) Induction of somatic embryogenesis as an example of stress related plant reactions. Electron J Biotechnol $13: 4$

[65] Zheng Q, BAO, Ju L, Likun K, Xiao X (2005) Effects of antioxidants on the plant regeneration and GUS expressive frequency of peanut (Arachis hypogaea) explants by Agrobacterium tumefaciens. Plant Cell Tiss Org Cult 81:83-90 